\title{
Deodorizing and Antibacterial Properties of Herbal Oil Finished Fabric
}

\author{
"Dr. Geethadevi, "Dr. V. Maheshwari \\ *Assistant professor, \#ASSOCIATE professor, PSG College of Arts and Science, Coimbatore, India. \\ "geets_fashion@yahoo.co.in, "annaisiddu@gmail.com
}

\begin{abstract}
Deodoring finish can not only remove the odours of textiles but also increase the value-added of the products. Deodorizing and antibacterial textiles has gained much popularity in the market. This study is focused on the development of deodorizers and bacterial resistant finished fabric using herbal oil combination. The two different essential oil like Cypress oil and Thyme oil were combined in three combinations like (1:1), (2:1) and (1:2) and was finished on 50:50 Bamboo/Tencel blended fabric by dip-dry method. The finished fabric was analysed for deodorising activity by Oraganoleptic test method and anti-bacterial activity by AATCC 100-2004 test method. The result showed essential oil combination (2:1) ratio had excellent deodorizing property and also the result indicates good efficiency against both the bacteriae Staphylococcus aureus and Escherichia coli in (1:2) essential oil combination ratio.
\end{abstract}

Key words: Antibacterial, bacterial resistant, Cypress oil, Deodorizers, Oraganoleptic test, and Staphylococcus aureus.

\section{INTRODUCTION}

Textiles had an important role in both technological and artistic development for evolution of human culture[1]. Clothing consider to be the second skin. Functionality of clothing depends on arttributes such as wrinkle resistance, soil release, water repellency, flame retardancy and resistance to microbial invasion textiles serve as excellent substrate for bacterial growth and microbial proliferation und/er appropriate moisture and temperature [2].

Bamboo fibre is a revolutionary new fibre and the fabric which is made from bamboo fibre has unparalleled advantages, including strength, versatility, softness and luxurious texture. In a very short time, clothing made it to the top ranks of eco-friendly choice[3].

The Tencel fibre is used to make textiles for clothing and other purposes. It shares many properties with other cellulosic fibres such as cotton, linen, ramie and rayon. Some main characteristics of Tencel fibres are soft and resistant to wrinkles. Tencel fabric can be machine or hand washed or dry cleaned, it drapes well, and many colours can be dyed with Tencel and can simulate a variety of textures such as suede, leather, and silk [4]

A fibre blend is an intimate mixture of fibres of different composition, lengths, diameters or colours, spun together into one yarn. Blending yarns are produced by blending or mixing single or ply yarns with different fibre species. It also minimizes fibre costs and improves quality[5] .

Knitted fabrics are highly valuable due to their porosity, moisture absorption, and air and vapour permeability, nice touch, comfort, body fit, good elasticity and easy care.
Therefore, they are often used for competitive and recreational sport products, T-Shirts, tracksuits, cycling, football and basketball, outfits, swimwear, socks, head-and wrist sweat bands, hats, ski and snowboard sweaters etc. even[6] .

Now a days focus is on made cloths are produced with the textiles coated with plant based extract with antibacterial activity[7]. Human beings are protected well by the fabrics treated with antimicrobial finish against microbes. The antimicrobial finish at present is imparted to specialty products in the medical, technical, industrial, home furnishing and apparel catagories.Although, number of commercial antimicrobial agents have been introduced in the market, their compliance with the regulation imposed by international bodies like EPU (Economic Policy Uncertainty) is still a critical issue. Hence, there is development in investigation of Eco-friendly natural antimicrobial finish from herbs for application on textile substrates[8]. Deodorant and antimicrobial treatment are rapidly becoming a standard finish in some textile categories and should be viewed as a finish with a future using natural sources[9]. The oil was analysed to reveal the presence of smaller and volatile molecules[10].

The purpose of this study is to examine the deodorizing property and antibacterial activity by application of herbal oil combination.

\section{METHODOLOGY}

\section{SELECTION OF FABRIC}

The fabric selected for the investigation is 50:50 Bamboo/Tencel blended with the following specification. 
Yarn count: 40s. Fabric type: single jersey fabric. It was scoured, bleached and dyed to attain basic preparatory process.

\section{SELECTION OF OIL}

Oil like Cypress (Taxodium distichum) and Thyme (Thymus vulgaris) was selected for the study and were purchased in swastik eucalyptus oil, Ooty.

\section{SELECTION OF OIL FOR COMBINATION AND THEIR RATIOS}

Cypress oil and Thyme oil were selected for oil combinations. The selected combinatorial ratios are given below.

$1: 1-50 \%: 50 \%$

$2: 1-75 \%: 25 \%$

$1: 2-25 \%: 75 \%$

\section{METHOD OF FINISHING}

The selected fabric was finished separately with herbal oil combinations by dip dry method. The fabric was immersed in the oil combination for 15 minutes separatley for each oil. The fabric was taken out of bath and sqeezed. The fabric was finally dried in ambient air. The efficiency of finished fabric was tested by Oraganoleptic test and AATCC 100-2004.

\section{EVALUATION OF DEODORANT ACTIVITY BY ORGANOLEPTIC METHOD}

Every day each male panelist was given a treated fabric during the test period. Each sample was kept under the socks worn on a specific foot. At the end of a stipulated period of time, panelists removed the samples and incubated till next day. The selected four Judges (Odour judges) evaluated the samples after 14 hours of removal on each test day. The judges were given individual scoring sheets to evaluate every day. The odor grading scale was 0 to 10 (0- Repulsive, 1- Very poor, 2- Poor, 3- Poorly Fair, 4- Fair, 5- Acceptable, 6- Fairly Good, 7- Good, 8- Very Good, 9- Excellent, 10- Ideal ).

QUANTITATIVE EVALUATION OF THE ANTIBACTERIAL ACTIVITY OF HERBAL OIL FINISHED FABRICS USING THE STANDARD AATCC TEST METHOD 100 - 2004

All the controlled and finished fabrics were subjected to antibacterial assay. The assay used for measuring antibacterial properties was based on the AATCC Test Method 100-2004. Briefly, one milliliter of 12 hours challenged bacterial inoculum was dispersed as droplets over the three swatches (test fabrics) using a micropipette. The swatches were inoculated in pre-sterilized 250 milliliter Erlenmeyer flasks. After all the samples were inoculated, the flasks were incubated at $37 \pm 2{ }^{\circ} \mathrm{C}$ for 18 hours before being assayed for bacterial population density. The bacterial population density was determined by extracting the bacteria from the fabric by adding $100 \mathrm{ml}$ of distilled water to each flask and shaken using an orbital shaker for one minute. Then aliquots were serially diluted and pour plated to determine the bacterial density. The difference in number of viable bacteria were evaluated on the basis of the percentage reduction. Percentage reduction was calculated using the formula $R=(B-A) / B X 100$. Where, $R$ is coded for percentage reduction. $A$ is the number of bacteria in the broth inoculated with finished test fabric immediately after inoculation i.e., at zero contact time and $B$ is the number of bacteria recovered from the broth inoculated with finished test sample after the desired contact period of 18 hours.

\section{GAS CHROMATOGRAPHY- MASS SPECREUM (GC-MS) ANALYSIS}

The test were done with the instrument Hewlett Packard 5890, Gas Chromatograph with 5970 Mass Selective Detector, a HP 5970c MS chemstation, and a HP 7946 disc drive. A fused-silica capillary column coated with coating on a fused silica capillary column coating was used. The Gas Chromatography temperature program was as follows: initial temperature was $100{ }^{\circ} \mathrm{C}$, held for one minute, and increased to $130{ }^{\circ} \mathrm{C}$ at a rate of $2{ }^{\circ} \mathrm{C} / \mathrm{min}$, then to $200^{\circ} \mathrm{C}$ at a rate of $3{ }^{\circ} \mathrm{C} / \mathrm{min}$, and finally to $280^{\circ} \mathrm{C}$ at a rate of $6^{\circ} \mathrm{C} / \mathrm{min}$ and held for $10 \mathrm{~min}$. The split ratio was 1: 2 , injection temperature was $250^{\circ} \mathrm{C}$ transfer line temperatures was 270 ${ }^{\circ} \mathrm{C}$, and ion source temperature was $200{ }^{\circ} \mathrm{C}$. The mass spectrometer was operated at $70 \mathrm{eV}$ in the electron impact mode with SCAN or selected ion monitoring (SIM).

\section{RESULT AND DISCUSSION}

\section{EVALUATION OF DEODORANT ACTIVITY BY ORGANOLEPTIC METHOD}

\begin{tabular}{|c|c|c|c|c|}
\hline \multirow{2}{*}{ Judges } & \multicolumn{4}{|c|}{ Fabric samples } \\
\cline { 2 - 5 } & $\begin{array}{c}\text { Controlled } \\
\text { fabric }\end{array}$ & $\begin{array}{c}(\mathbf{1 : 1}) \\
\text { Ratio }\end{array}$ & $\begin{array}{c}(\mathbf{2 : 1}) \\
\text { Ratio }\end{array}$ & $\begin{array}{c}(\mathbf{1 : 2}) \\
\text { Ratio }\end{array}$ \\
\hline 1 & 3 & 6 & 9 & 8 \\
\hline 2 & 4 & 7 & 8 & 6 \\
\hline 3 & 3 & 5 & 8 & 8 \\
\hline 4 & 2 & 7 & 9 & 7 \\
\hline $\begin{array}{c}\text { Average of } \\
\text { Ratings }\end{array}$ & 3 & 6.25 & $\mathbf{8 . 5}$ & 7.25 \\
\hline Intaty & & & & \\
\hline
\end{tabular}

Interpretation: 0-Repulsive, 1- Very poor, 2-Poor, 3- Poorly Fair, 4-Fair, 5-Acceptable, 6- Fairly Good, 7- Good, 8- Very Good, 9-Excellent

Table :1 Deodorant activity of herbal oil combination

Table 1 furnished above show the deodorant activity in oil finished fabric. While comparing the controlled and oil finished sample, it represents that the fabric treated with $(2: 1)$ oil combination ratio showed an very good to excellent aroma. In case of other combinations it shows fairly good and good interpretation. Thus it could be concluded that sample finished with cyprus and thyme oil $(2: 1)$ combination had the highest deodorizing property

QUANTITATIVE EVALUATION OF THE ANTIBACTERIAL ACTIVITY OF HERBAL OIL COMBINATION FINISHED FABRICS USING THE STANDARD AATCC TEST METHOD 100 - 2004. 


\begin{tabular}{|l|l|c|c|c|}
\hline \multirow{2}{*}{$\begin{array}{l}\text { \% Reduction of } \\
\text { Bacterial count }\end{array}$} & \multirow{2}{*}{ Fabric sample } & \multicolumn{3}{|c|}{$\begin{array}{c}\text { Herbal Oil } \\
\text { Combination }\end{array}$} \\
\cline { 3 - 5 } & & $\mathbf{1 : 1}$ & $\mathbf{2 : 1}$ & $\mathbf{1 : 2}$ \\
\hline $\begin{array}{l}\text { Staphylococcus } \\
\text { aureus }\end{array}$ & $\begin{array}{c}\text { Bamboo/Tencel } \\
\text { Controlled fabric }\end{array}$ & \multicolumn{3}{|c|}{0} \\
\cline { 2 - 5 } & Bamboo/Tencel & 28 & 75 & 89 \\
\hline \multirow{2}{*}{ Escherichia coli } & $\begin{array}{c}\text { Bamboo/Tencel } \\
\text { Controlled fabric }\end{array}$ & \multicolumn{3}{|c|}{0} \\
\cline { 2 - 5 } & Bamboo/Tencel & 64 & 85 & 90 \\
\hline
\end{tabular}

Table :2 Antibacterial activity of herbal oil combination

The table 2 showed the Antibacterial activity of fabric samples treated with Thyme \& Cyprus with different oil combination like (1:1), (2:1) \& (1:2), against Staphylococcus aureus and Escherichia coli. While comparing the controlled sample with the finished sample, the controlled sample had no antibacterial activity, whereas thyme and cyprus oil combination (1:2) ratio finished sample was found to be effective against both the organisms Staphylococcus aureus and Escherichia coli comparing to other ratio finished sample.

\section{GAS CHROMATOGRAPHY- MASS SPECROMETRY (GC-MS) ANALYSIS}

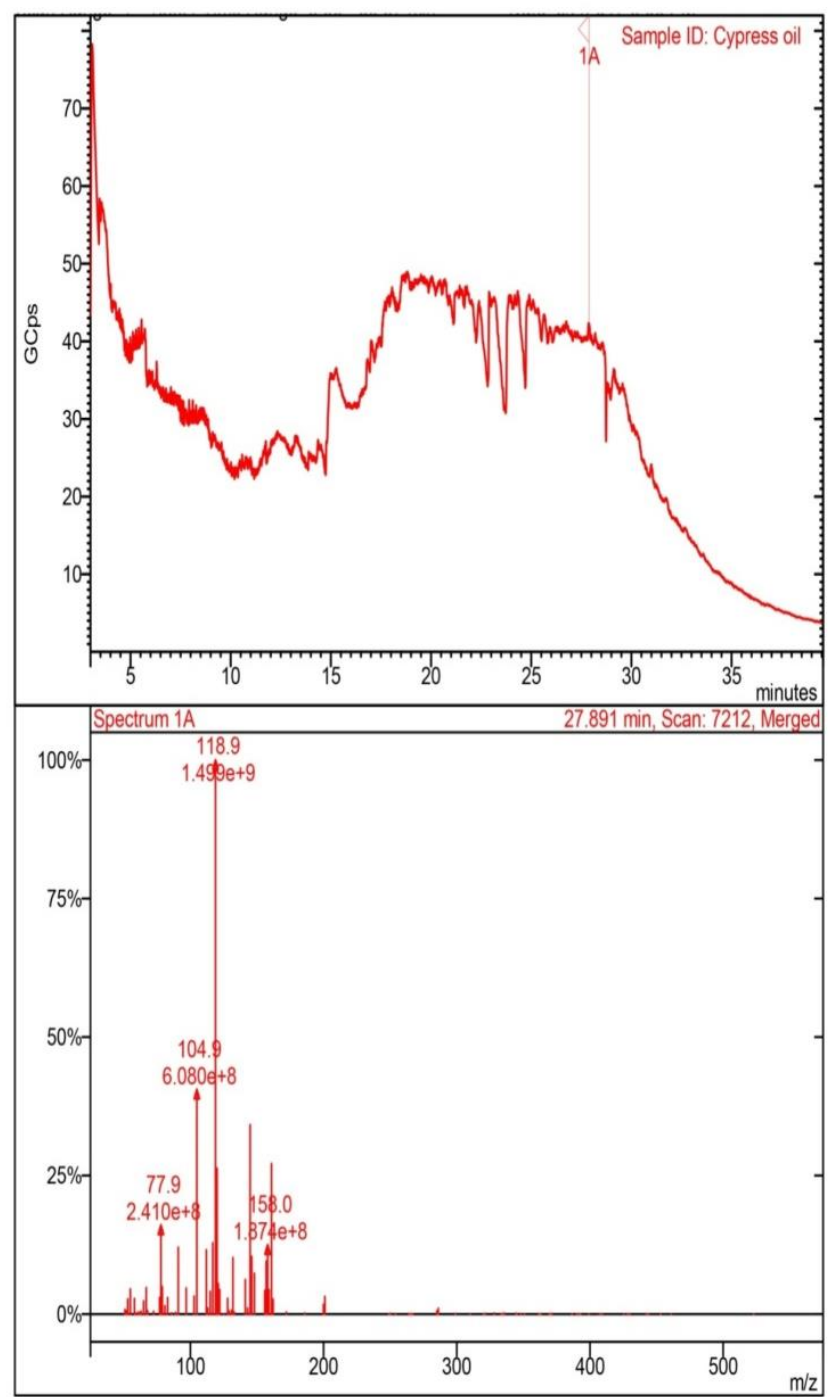

Figure 1. Gas Chromatography- Mass Specrometry (GC-MS) Analysis of Cypress oil
The above figure 1 showed the percentage of compounds present in cypress oil. The peak showed the maximum percentage of compound identified was geranyl-p-cymene (C14H2402) and 1-,5- Decadine (C10H14).

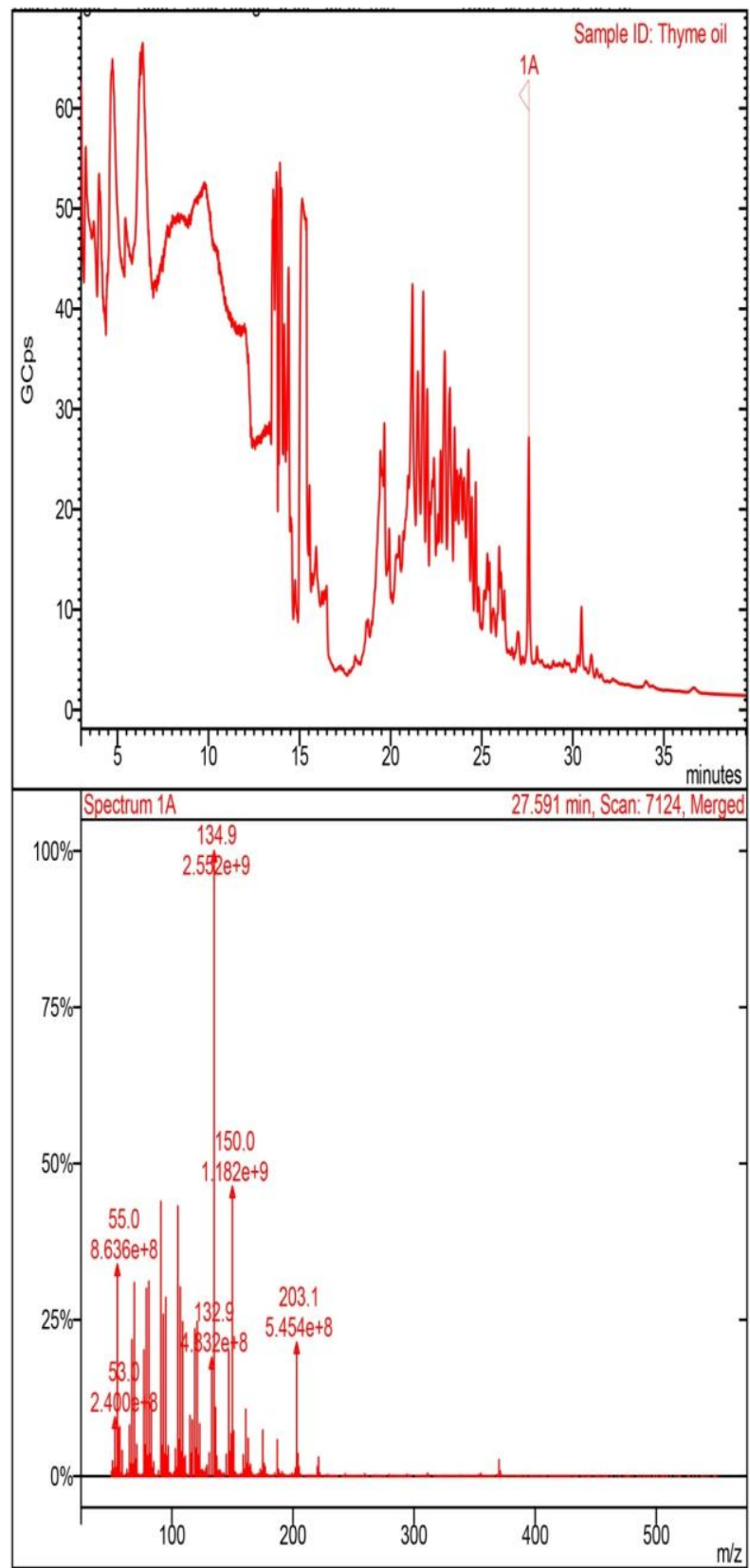

Figure 2 Gas Chromatography- Mass Specrometry (GCMS) Analysis for Thyme oil

The above figure 2 for thyme oil shows the compounds present in the oil with percentage, molecular formula, retention time. The peaks showed the presence of Cyclohexene $(\mathrm{C} 11 \mathrm{H} 18)$, alfa.6paene $(\mathrm{C} 15 \mathrm{H} 24)$ as the maximum percentage in oil.

\section{CONCLUSION}

The two oil Cypress and Thyme were selected for oil combinations. The three different oil combinations were selected and analysed for their deodorant and antibacterial property. The result revealed that for deodorant and antibacterial property, cypress oil and thyme oil 
combination had showed better results. The oil combinaton (2:1) showed very good to excellent interpreted value for deodrant activity. For antibacterial activity, the oil combination (1:2) has good inhibitory activity against both the bacteriae Staphylococcus aureus and Escherichia coli. Thus by observing the overall results from the study for deodorant and antibacterial finish for textile materials, essential oil combination is suggested.

\section{REFFERENCES}

[1] Gopalakrishnan.D, (2006), Antimicrobial finishes, Man-made Textiles in India, 49(10) 372- 377.

[2] Jyothi V. Vastrad and Shameembanu A.Byadgi (2018), Eco-friendly Antimicrobial finishing of cotton fabric using extracts, International journal of current microbial applied science, 7(2), 284-292.

[3] Avernita Srivastava, Rohini and DR M S Parmar (2013), Innovative fragrance finish on bamboo fabric, The Indian Textile Journal, 123(9), 43.

[4] http://businesscasestudies.co.uk/tencel/developing-aproduct/research-anddevelopment.html\#ixzz2XUE8v82P.

[5] http://www.ask.com/question/what-is-a-fibre-blend

[6] Andrej-Vilar, KlementinaMozina and Prof Alenka, Pavko-Cuden, (2013), Knitting International, Lettering Know-how, 5, 26.

[7] Jyoti V. Vastrad and Shameembanu A.Byadgi, (2018), EcoFriendly antimicrobial finishing of cotton fabric using extracts, International Journal of Current Microbiology and Applied Science, Vol 7, No 2 .

[8] Thilagavathy. G, Rajendran .R \&Krishnabala .S,(2016) Herbal Antimicrobial Finish Using Microencapsulation Technique, Functional and Textile Apparels .43.

[9] Prasanta Sarkar (2015), Textile Finishing: Different Types of Chemical Finishes for Textiles, Online clothing study.

[10] Shu Han Feng, Qi Shen \& Sha Chen (2019), Essential Oil Profiles of 168 Perilla Cultivars by Head Space Solid Phase Micro-extraction Gas Chromatography Mass Spectrometry, Journal of Essential oil Bearing Plants. 